\title{
Assessment, Determination and Modeling Effects of Infrastructural Decay on Rental Values in Nigeria (Case Study of Ehimiri, Agbama and Isieke Housing Estates)
}

\author{
Casmir Chidiebere Onyeneke ${ }^{1}$, Chibuzor Eguzouwa ${ }^{2}$ \\ ${ }^{1}$ Department of Mathematics and Statistics, Hezekiah University, Umudi, Nigeria \\ ${ }^{2}$ Department of Estate Management, Abia State University, Uturu, Nigeria
}

Email address:

casdyx@yahoo.com (C. C. Onyeneke), eguzouwa_chibuzor@yahoo.com (C. Eguzouwa)

\section{To cite this article:}

Casmir Chidiebere Onyeneke, Chibuzor Eguzouwa. Assessment, Determination and Modeling Effects of Infrastructural Decay on Rental Values in Nigeria (Case Study of Ehimiri, Agbama and Isieke Housing Estates). Engineering Mathematics.

Vol. 2, No. 1, 2018, pp. 12-20. doi: 10.11648/j.engmath.20180201.12

Received: May 31, 2018; Accepted: June 12, 2018; Published: July 9, 2018

\begin{abstract}
Housing accessibility and utilities constitute the intangible services available to a particular building by a community or any activity or groups of activities operated within the community. This research examines the effect of the decays in these infrastructures on rental values. The more accessible a dwelling is relative to other activity areas, the more useful will the dwelling be. Generally, infrastructural utilities include such goods and services as the provision of potable water, electricity, sewage, telephone, gas and roads. The provision of these utilities is not without cost and this cost is usually included in or forms part of the cost of housing. Many developing countries, particularly in Africa, accord relatively low priority to housing in their overall scheme of national development, and the volume of construction generally falls short of housing demands. The approach to housing policy in Nigeria has tended to oscillate between the welfare mixed economy and the free market model. The conventional wisdom is that governments should focus on providing good investment climates, infrastructure and mortgage facilities to low and middle income families. Nigerian cities are largely characterized by the public provision of urban infrastructural services such as electricity, water supply, drainage, sewage, access road and solid waste collection and disposal. The three tiers of government federal, state and local are often involved in one way or the other in the provision of these services in the urban centers. Although the provision of infrastructures such as roads and power supply lies with the government, communal efforts are still put together to fast track the process of making the infrastructures reach the people. Sometimes it is preferable not to wait for the government due to administrative bottlenecks and sometimes corruption by government officials.
\end{abstract}

Keywords: Infrastructure, Housing Facilities, Rental Values, Electricity, Basic Amenities, Correlation Coefficient, Regression, Estate Management

\section{Introduction}

Over the years there has been high level of decay as regards in shortfalls of infrastructure maintenance in Nigerian housing estates and Abia state in particular. Quite a number of estates provided by governments as well as individuals in order to make accommodation reachable to the low and middle income earners have never been given adequate attention which has gradually led to the ineffective functioning of these housing estates. Infrastructural amenities in such estates are meant to be upgraded from time to time. But sadly, what is found in most of the estates built and managed by the government is that they are usually neglected with little or no attention from the government. Ever since the creation of these estates (Ehimiri, Agbama and Isieke housing estates), there has been a population explosion which has taken its toll on the existing infrastructures. Road maintenance has been a struggling factor which has grieved the mind of inhabitants who battle with traffic congestion when moving in and out of the estates. The problem stems from the fact that the constructed roads especially tarred roads, asphalt surfaced roads were substandard and often get damaged from the bottom to the top especially when poorly drained water seeps into them 
after heavy rainfall. In spite of taxes and levies paid by occupiers to physical planning and infrastructures development fund for the provision and maintenance of some basic infrastructure like roads, and street lights, the situation remains the same because the department in charge have not bothered to maintain the road, drainage, street lights, boreholes etc. Recently, electricity has become of great displeasure in the neighbourhood due the ineffective functioning of transformers which has been in service since the inception of these housing estates. Nevertheless no concerted effort has been put in place towards replacing the outdated transformers which frequently blow resulting to breakdown of power. The inter-street road networks have become a hiding zone for hoodlums who have taken the condition of infrastructure in the estates as an advantage thereby making life challenging for the inhabitants.

Up till now no effort has been made by government to restore back the existing stationed overhead water supply in Ehimiri housing estate which has now become an abode for vultures and all manner of birds. Due to poor or unfriendly environmental attitudes of some residents, refuse is being piled up in streets making the environment unhygienic for living. In this regard no waste disposal system has been provided to some of these estates in which Agbama housing estate is not an exception. Owing to the fact that there is a direct relationship between urban infrastructure and rental values, accessibility which is a direct consequence of a good road network in turn leads to high rental values of locations with greatest accessibility advantages. This is evident in Agbama Housing Estate where the quest for housing decreases in areas void of infrastructures. In a situation where all properties are accessible via motorable road network, such properties will enjoy high rental values conferred by virtue of accessibility. It has become necessary to carry out a research of this kind in order to evaluate the effects of infrastructure on the selected housing estates in Abia State (Ehimiri, Isieke and Agbama housing estates). Comparison will also be made to ascertain if there is any relationship each of the infrastructure to be discussed has on the housing estates

While there is no universally recognized definition of infrastructure, there is a broad agreement about what it is and is not. Thus it was defined as the structural elements of an economy that facilitates the flow of goods and services between buyers and sellers. According to [1], infrastructure refers to resource systems that have been harnessed for the development of a society. Such systems include telecommunication, energy, transportation, governance and other public utilities. The definition includes the activities possible by providing transportation and other facilities in which community activities can take place [2]. The definitions are alike in identifying as infrastructure such assets as roads, railways and sewage systems. The broader social capital definitions also take in housing, health and education, services and also some other social institutions that facilitate economic and social interaction. Several authors have defined infrastructures from different perspectives. Infrastructure is synonymous with facility which includes buildings, structures and apparatus by which services essential to the development and use of landed properties.

The [3] defined it as "the large-scale public systems, services, and facilities of a country or region that are necessary for economic activity, including power and water supplies, public transportation, telecommunications, roads, and schools". The World Health Organisation also defined it as "all necessary services, facilities, equipment and devices needed or desired for the physical and mental, health and social well-being of the family and individual". It was described it as "the stock of fixed capital assets in a country for example roads, railways, airports, waterways, Power stations, waterworks, hospitals and telecommunication network. All these with the attendant transportation network, electricity supply, telephone services and wholesome water supply and Medical services invariably constitute infrastructural facilities". It serves as a slender threads that weaves together human needs and values with those of the environment. Literally, it refers to fixed facilities or installations traditionally provided by the public sector. It is the systematic framework, which underpins a community's ability to fulfil its mission of providing a base for its citizens to be productive and to nurture social equity.

Infrastructures by nature are better provided by the government for its respective communities. It is elaborated in [4] that the scope of infrastructures is synonymous with public utilities, community facilities and services. Public utilities include water supply, electricity supply, gas supply, sewerage, telephone service and storm water drainage. Social (community) facilities include Educational facilities, Health facilities, Post Office and Postal agencies, shopping areas, Recreational areas and facilities, Religious buildings, Cultural facilities like Libraries, Art galleries and Museum. Social (community) services are Police protection, Fire protection, Street cleaning and maintenance, Street lighting, and Garbage and Refuse collection and disposal. By these definitions, infrastructure refers to the basic facilities and services essential to institution, economic and social development. They constitute the main fabric of what may be called institutional physical system linked to property development and use. They include Road, Street, Bridge, Other transport facilities, Education, Health services, Water supply, Power supply, Telecommunication facilities, Waste disposal system, Recreational facilities, etc. It was viewed as an enterprise or the products, services and facilities necessary for an economy to function [5]. The Duo extended the view as the set of interconnected structural elements that provide framework supporting an entire structure of development. It is the means of achieving an objective or set of objectives. It is an important term for judging a country, region or state's and individual's developments/status.

The term typical refers to the technical structures that support a society, such as roads, water supply, sewers, electrical national grids, telecommunications and, and so forth and can be identified as the physical components of 
interrelated systems providing commodities and services essential to enable, sustain or enhance societal living conditions [6]. Aiming to highlight general features of "goods" from time to time utilised can be said that the term "infrastructure" - stemming from the usage of military language (where it refers to permanent military installations such as barracks and airports) - in economic sense refers to two main criteria: Infrastructure is a capital good (provided in large units) in the meaning that it is originated by investment expenditure and is characterised by long duration, technical indivisibility and a high capital-output ratio. Infrastructure is also a public (sometimes a merit) good, not necessarily in the sense that it is owned by the public sector, rather in the proper economic sense that it fulfil the criteria of being not excludable and not rival in consumption for which economic agents show real (in the case of merit goods) or opportunistic (in the case of public goods) "wrong" preferences. Sometimes the characteristic of being a public good is weakened so that infrastructures do create external effects but do not achieve the maximal level of externalities represented by public goods.

From the foregoing, an infrastructure can then be said to be the whole gamut of facilities that enables a society to function effectively which refers to both hard and soft infrastructure system generally owned and operated by municipal/urban governments. These include water supply, sanitation, solid waste management, bridges and roads, public libraries, educational and health facilities. They are basically infrastructures that affect the competitiveness, liveability and sustainability of cities. They are provided to ensure efficient functioning of the urban system. These facilities are traditionally provided by local, state and federal governments and their agencies. In other words it provides the catalytic base for facilitate the production of goods and services, and also the distribution of finished products to the market, as well as basic social services such as schools and hospitals. Essentially therefore, infrastructure refers to the interconnected and interrelated network that provides base for industrial production, connects goods to the markets, workers to industry and people to services [7].

Considering the relevance of infrastructure to this dissertation, it is pertinent to trace the history of infrastructure in Nigeria as it will give an insight into this research. Nigeria emerged as a country in 1914 when the British Colonial administration amalgamated the southern and northern protectorates. The country was administered with three regions in 1946-1963, four regions in 1964-1966, 12 states in 1967-1975, 19 states in 1976- 1986, 21 states in 1987- 1990, 30 states in 1991-1995, and 36 states in 1996 respectively [8]. The country has also been divided into six geo-political zones and 774 local government areas since 1999-1996 respectively. The Nigerian population was over 140million during the 2006 census. Nigeria was primarily driven by agriculture from 1914 up till the 1960s, whereas with a decline in agricultural production, the petroleum resources became a major source of Nigeria's revenue in the 1970s [9]. But the collapse of the prices of petroleum products in the early 1980's as followed by macroeconomic imbalances, leading to adoption of Structural adjustment programme (SAP) prescribed by the international monetary fund(IMF) and the World Bank.

The SAP led to the increase in the gap between the rich and the poor and intensification of poverty in Nigeria. The foregoing sets a stage for the discourse on infrastructure in Nigeria. The original efforts geared towards provision of Infrastructure in Nigeria were quite impressive whereas the efforts nose-dived since the advent of imperialism and its triplets named slave trade colonialism and neo-colonialism. Nkrumah (1965) recognized the neo-colonialism as the last stage of imperialism. Experience with slave trade and colonialism cannot be forgotten in Nigeria. Following the abolition of slave trade, the Nigerian kingdoms were colonised. This overshadowed the distinctive artefacts and colonialism of skilled artisans and Iron workers among the Nok people. Subsequently traditional infrastructure found among the Nok, Igbo- Ukwu, Benin, Yoruba was modernized in the context of colonialism. Colonialism resulted to the establishment of new institutions such as armed forces, public service, hospitals and energy factor. The major infrastructure established during the colonial era included electricity, tarred roads, pipe borne water, railways, ports, communication networks, health centres and schools. However, these colonial infrastructures served a few elite who lived in cities where the infrastructures could only be accessed. The crop of Nigerian leaders who succeeded the colonial governors attempted to maintain and extend the inherited colonial infrastructure but failed due to official negligence and mismanagement of resources. This act of mismanagement set in decay which has generally affected every infrastructure built in recent times including ones situated in housing estates in Nigeria.

Real property is defined as land, buildings and other improvements thereon and the legal rights relating to the asset - land [10]. However, this definition is somewhat confusing as there is always a distinction between real property and real estate, though both terms are sometime used interchangeably in real estate profession literature and practice [11]. Real property is defined as only the interests, benefits, and rights inherent in the ownership of real estate, while real estate is defined as only the physical land and the improvements thereon [12]. This distinction clarify that real property cannot be both land and rights and that is the reason why most appraisers are concerned in the interests substituting in the property than the property per se. At the same, the classification is according to their forms of ownership, use, etc., and which could be classified into possessory real property and non-possessory real property [13]. The real property in any of its investment sector has the characteristics which are distinguishable from other investments, and to this, [14] typically identified as including heterogeneity, risk, liquidity, and indivisibility. Others are: high cost of transfer; holding cost; income and capital growth; special ownership gains; imperfect knowledge; perpetuity; and leverage or gearing [15]. 
However, the discussion above is not out of place, but the study context is on property value. Therefore, property value according to [16] is the amount of money which can be obtained for the interest on a property at a particular time from persons able and willing to purchase it. Value in this case is not intrinsic but results from estimates made subjectively by able and willing purchasers of the benefits or satisfactions they will derive from ownership of the interest [17]. This applaud that value does not exists on its own but is created by certain condition and/or circumstances such as: its utility; scarcity; desirability; and effectiveness or effective purchasing power [18]. There must be a strong association between these conditions in relation to the property demand and supply otherwise the property value would be inherent. There are only two well known forms of property value such as capital value and rental value. But, [19] clarified that real property value comprises of the: market value, value-in-use, going concern value, investment value, liquidation value, assessed value, and insurance value.

Therefore, these values should be sustained in any real property through availabilities of adequate infrastructural provisions such as those earlier mentioned. But, where these infrastructural projects are not provided in the housing estates, the consequences should bring a reduction on the combined values of what the properties ordinarily should have being when these infrastructures are completed and provided in the area. This is in a similar agreement with the assertion of [20] that infrastructural projects abandonment would always affect property values in the vicinity. The housing condition of a country is a pointer to the health motivation, economic well-being and the social circumstances of her citizens. Housing touches on the life of an individual as it provides the space for protection, privacy, economic activities, recreation and livelihood. To most groups, housing means shelter but toothers it means more as it serves as one of the best indicators of a person's standard of living and his or her place in the society [21] Adequate supply of housing has remained a mirage to all cadres of the society in Nigeria. Rapid growth in population creates demand pressure towards shelter and efficient supply and distribution of basic utilities and services for city dwellers. In most urban centres, the problem of housing is not only restricted to quantity but to the poor quality of available housing units.

Nigeria is perhaps the fastest urbanizing country in the African continent. The rapid growth rate of urban population in Nigeria since the early seventies was mainly due to immigration induced by the concentration of the gains from the oil sector in the urban areas. The phenomenal rise in population, number and size of cities over the past few years have manifested in the acute shortage of dwelling units which resulted in overcrowding, high rents, poor urban living conditions, and low infrastructure services and indeed high crime rates. One major aspect of urban problem with respect to housing is the poor state of the infrastructures [22]. A study of housing situation in Nigeria put existing housing stock at 23 per 1000 inhabitant and housing deficit is put at 15 million houses [23]. Research has shown that $75 \%$ of urban housing is situated in slum conditions and indeed the quality of the housing is poor and clearly an affront to human dignity [24]. An important challenge facing the country is the provision of affordable housing and basic infrastructures. As more and more Nigerians make towns and cities their homes, the resulting social, economic, environmental and political challenges need to be urgently addressed [25]. Various authorities have proffered strategies for improving housing delivery in Nigeria. The cooperative housing model was suggested by [26] while [27] suggested affordable financing model. It has been observed that house ownership is one of the first priorities for most households and it represents the largest single investment for most people, taking up between 50 percent and 70 percent of household income.

\section{Research Methodology}

Sampling technique is defined as the method used in selecting respondents. For this research the researcher has two major categories of respondents for whom this questionnaire been structured. The first category of respondents was owners/landlords and tenants who are occupiers of such properties. Bearing in mind that our sample size is 94 housing units which is occupied by either the owners or tenants and the study area is made up of three housing units all in Umuahia North local government local government area, the researcher gave Ehimiri housing estate a sample of 35, Agbama housing estate a sample of 32 and Isieke housing estate a sample of 27 . This follows that 35 questionnaires will be distributed in Ehimiri housing estate while 32 and 27 will be distributed in Agbama Housing estate and Isieke housing estate respectively. The situation of the identified indispensable infrastructures in the housing estates were examined and recorded.

Table 1. The Situation of the Identified Indispensable Infrastructures in the Housing Estates.

\begin{tabular}{|c|c|c|c|c|c|c|}
\hline \multirow{3}{*}{ Attributes } & \multirow{2}{*}{\multicolumn{2}{|c|}{ Ehimiri Housing Estate }} & \multirow{2}{*}{\multicolumn{2}{|c|}{$\begin{array}{l}\text { Agbama } \\
\text { Housing Estate } \\
\end{array}$}} & \multirow{2}{*}{\multicolumn{2}{|c|}{$\begin{array}{l}\text { Isieke } \\
\text { Housing Estate }\end{array}$}} \\
\hline & & & & & & \\
\hline & Freq & $\%$ & Freq & $\%$ & Freq & $\%$ \\
\hline \multicolumn{7}{|l|}{ Road Situation } \\
\hline Tarred but washed & 1 & 2.94 & 5 & 16.67 & 4 & 14.81 \\
\hline Un-tarred & 2 & 5.88 & 22 & 73.33 & 20 & 74.07 \\
\hline Non-useable by motors & 0 & 0 & 1 & 3.33 & 2 & 7.41 \\
\hline \multicolumn{7}{|l|}{ Electricity Supply Situation } \\
\hline Provided and Supplying Electricity & 24 & 70.59 & 15 & 50 & 13 & 48.15 \\
\hline
\end{tabular}




\begin{tabular}{|c|c|c|c|c|c|c|}
\hline \multirow{3}{*}{ Attributes } & \multirow{2}{*}{\multicolumn{2}{|c|}{ Ehimiri Housing Estate }} & \multirow{2}{*}{\multicolumn{2}{|c|}{$\begin{array}{l}\text { Agbama } \\
\text { Housing Estate }\end{array}$}} & \multirow{2}{*}{\multicolumn{2}{|c|}{$\begin{array}{l}\text { Isieke } \\
\text { Housing Estate }\end{array}$}} \\
\hline & & & & & & \\
\hline & Freq & $\%$ & Freq & $\%$ & Freq & $\%$ \\
\hline Provided and Not Supplying Electricity & 4 & 11.76 & 14 & 46.67 & 10 & 37.04 \\
\hline Under Construction & 0 & 0 & 0 & 0 & 0 & 0 \\
\hline \multicolumn{7}{|l|}{ Portable Water Supply Situation } \\
\hline Provided and Supplying Water & 26 & 76.47 & 14 & 46.67 & 10 & 37.04 \\
\hline Provided and Not Supplying Water & 6 & 17.65 & 12 & 40 & 8 & 29.63 \\
\hline Not Available or Provided at all & 2 & 5.88 & 3 & 10 & 7 & 25.93 \\
\hline Under construction/Provision & 0 & 0 & 1 & 3.33 & 2 & 7.41 \\
\hline \multicolumn{7}{|l|}{ Drainage System Situation } \\
\hline Provided and Servicing the Estate Units & 28 & 82.35 & 1 & 3.33 & 2 & 7.41 \\
\hline Provided but Blocked & 2 & 5.88 & 3 & 10 & 3 & 11.11 \\
\hline Not provided at all & 4 & 11.76 & 26 & 86.67 & 10 & 37.04 \\
\hline Under Construction & 0 & 0 & 0 & 0 & 12 & 44.44 \\
\hline \multicolumn{7}{|l|}{ Waste Management System Situation } \\
\hline Provided and Servicing the Estate Units & 28 & 82.35 & 0 & 0 & 0 & 0 \\
\hline Not Available or Provided at all & 1 & 2.94 & 25 & 83.33 & 16 & 59.26 \\
\hline Under construction/Provision & 2 & 5.88 & 4 & 13.33 & 6 & 22.22 \\
\hline \multicolumn{7}{|l|}{ Recreational Facilities Situation } \\
\hline Provided and in Good Condition/Situation & 24 & 70.59 & 5 & 16.67 & 3 & 11.11 \\
\hline Provided and Not in Good Condition/Situation & 5 & 14.71 & 19 & 63.33 & 15 & 55.55 \\
\hline Not Available or Provided at all & 1 & 2.94 & 5 & 16.67 & 2 & 7.41 \\
\hline Under construction/Provision & 4 & 11.76 & 1 & 3.33 & 7 & 25.93 \\
\hline
\end{tabular}

The numbers of questionnaires distributed in each housing estate were arrived by:

$$
\frac{\text { noofhousingunits }}{\text { assesablepopulation }} x \text { Samplesize }
$$

The method of selecting these properties to be studied was by mere random sampling technique. This involves selecting respondents without a definite reason or pattern. The second category of respondents interviewed was Estate Surveyors and valuers who are saddled with the responsibility of managing of residential properties. The data requirement for the smooth conduct of this research is being systematically assembled from questionnaires, interviews, observations, internet sources, newspapers and publications. In other to avoid bias and skewness so as to ensure fair representation and judgment, consideration was given to the fact that the study area is made up of three housing estates with different population figures. This implies that notwithstanding the fact that the simple random sampling technique and judgmental sampling techniques was employed in determining the housing units in the three estates occupied by either landlord or tenants of whom were interviewed, equal chances were given to the three housing estates where questionnaires were administered.

Knowing that questionnaires are instruments for obtaining answers to research questions by using forms expected to be filled in by respondents, carefully structured questionnaires have been designed according to [28] which enabled the target respondents to provide objective information for the study with ease. Newspapers, articles, journals and other publications were also consulted to enhance the proficiency of this dissertation. Isieke Housing estate was established in 1993 after the creation of Abia state in 1991. It is located along Bende road which is a $50 \mathrm{~km}$ road that leads to Bende Local Government area of Abia State Nigeria. It measures an area of 49.051 hectres and is being bounded in the North by Isiodu, in the South by Nkata and Okwuta, in the West by Amuzukwu and in the East by Ihie and Iyienyi all in Umuahia North local Government area of Abia State. The Estate is located at the periphery of Umuahia and lying on the following coordinates $562372 \mathrm{E}$ and $170832 \mathrm{~N}$. It consists majorly of residential housing units with a total number of about 800 plots of land of which 450 housing units are fully developed for habitation, also with 8 commercial plots and 5 numbers of open spaces. (Source: Abia state housing and cooperation)

This housing estate known as Ehimiri Housing Estate was established in 2002 after consideration were made for the provision of more housing units that will accommodate most especially civil servants in the State. The Estate is located along Ikotekpene road that leads to AkwaIbom State. It is bounded in the North by Okwuta Village, in the South by OhokobeNdume, in the West by Okwuta Village and in the East by AhiekeNdume all in Umuahia North Local Government area of Abia State. It measures an area of 44.031hectres and lies on the following coordinates: $562342 \mathrm{~N}$ and $167879 \mathrm{E}$. It has a total number of 635 plots of land, 600developed residential plots of which 35 are still under construction for habitation, six commercial plots, three public plots and five numbers of open spaces. The layout Agbama housing estate was created by the Government in 2006 with the intention that it will go a long way in accommodating the teeming population. With an area of 51.452 hectres, the Estate is bounded in the North by Lodu, in the South by ItuOlokoro, in the West by Umuobia community and in East by Umuoparaozara all in Umuahia South Local government area of Abia State. Agbama Housing Estate is occupied by people of the low and middle income class. Major developments within the area are schools, corner shops, hotels, religions properties and residential properties. The estate is inhabited by people of 
diverse cultural and religious groups, majority of who are civil servants, public servants, and other privately employed. With a total number of 825 plots about 550 housing units are fully developed for habitation and it lies on the following coordinates: $562216 \mathrm{~N}$ and $171416 \mathrm{E}$.

\section{Results and Discussion}

At this point, we examined the level of relationship between infrastructural decay and rental values across the years. The essence is to ascertain the significant impact that infrastructure poses in the amount collected as rent in the study areas. Based on the analysis and scatter plot shown in Figure 1, there exists a positive relationship between infrastructure and rental value across the years. If rental value depends largely on the availability of infrastructure such as water, electricity, good road, drainage and many more, it then means the region with sustainable and much infrastructure tends to be more favourable to real property values as well as attract much rental values to property owners.

Table 2. Contribution of infrastructure to rental values.

\begin{tabular}{llll}
\hline Year & Infrastructure in 1000(X) & Rental Value in 1000(Y) & Control Estate(Zoo Estate)in 1000 \\
\hline 2004 & 1920 & 7824 & 150 \\
2005 & 2112 & 8442 & 160 \\
2006 & 2448 & 10482 & 165 \\
2007 & 2784 & 12060 & 166 \\
2008 & 3312 & 13452 & 185 \\
2009 & 3552 & 15480 & 230 \\
2010 & 4320 & 17020.8 & 250 \\
2011 & 4464 & 18144 & 290 \\
2012 & 4992 & 19440 & 290 \\
2013 & 5184 & 20448 & 320 \\
\hline
\end{tabular}

Table 2 was used to demonstrate the level of dependency of the rental value $(\mathrm{Y})$ on infrastructure across the years. Whatever happens to basic amenities in housing estates reflects in the value of the Real/landed properties. It either increases or decreases the rent. Rental value is directly proportional to infrastructure. In other words both are positively correlated according to [29] interpretation of correlation coefficients.

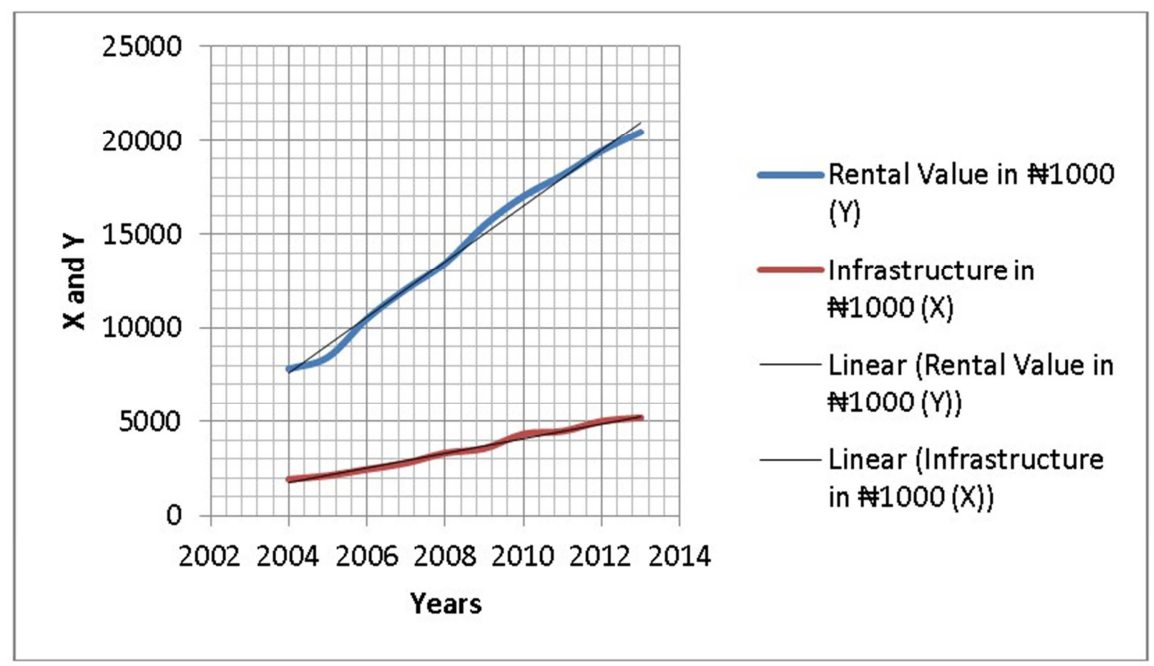

Figure 1. Relationship between rental value and infrastructureacross the years.

At this level, the trend of the relationship between infrastructural decay and rental value was analysed. It is important to examine if there exist a linear relationship [30]. We used regression analysis, analysis of variance and lackof-fit test to examine the effect of infrastructural decay. In this case infrastructure and rental value are significant model terms. Values 0.104 and 0.000 in the table below indicate the model terms are significant. This indicates that the two parameter are fit for the analysis of the effect of infrastructural decay in rental values. Since the availabilty of infrastructure in any localityremains the major determinant of the standard of living and value of real properties, we considered it as the major indices of ascertaining status of the selected housing estates.

Table 3. Infrastructure and Rental Value as indices of depreciation.

\begin{tabular}{llllll}
\hline \multirow{2}{*}{ Model } & & \multicolumn{2}{l}{ Unstandardized Coefficients } & \multicolumn{2}{l}{ Standardized Coefficients } \\
\cline { 3 - 5 } Sig. & B & Std. Error & Beta & \\
\hline \multirow{2}{*}{1} & (Constant) & 1017.261 & 554.551 & & 1.834 \\
& VAR00015 & 3.780 & .150 & .994 & 25.122 \\
\hline
\end{tabular}


The trend and and flow of infrastructural effects on rental value is presented as $y=3.78 x+1017.261$. The coefficient of determination, R-squared for the regression model was satisfactorily high at 0.987 which also reflected the degree of fit of the model parameters in analysing fall in infrastructure in housing estates, urban and rural amenities [30]. This indicates that 98.7 percent of the variations could be explained by infrastructural decrement and rental values. We went on to predict the values of real/landed properties and to propose a trend that shows the future rental values. Also it shows the diminishing level of infrastructure as in the future. Unless an urgent attention is created to raise and sustain the electricity, road, water, drainage, and road, there is an alarming level of devaluation in the three estates.

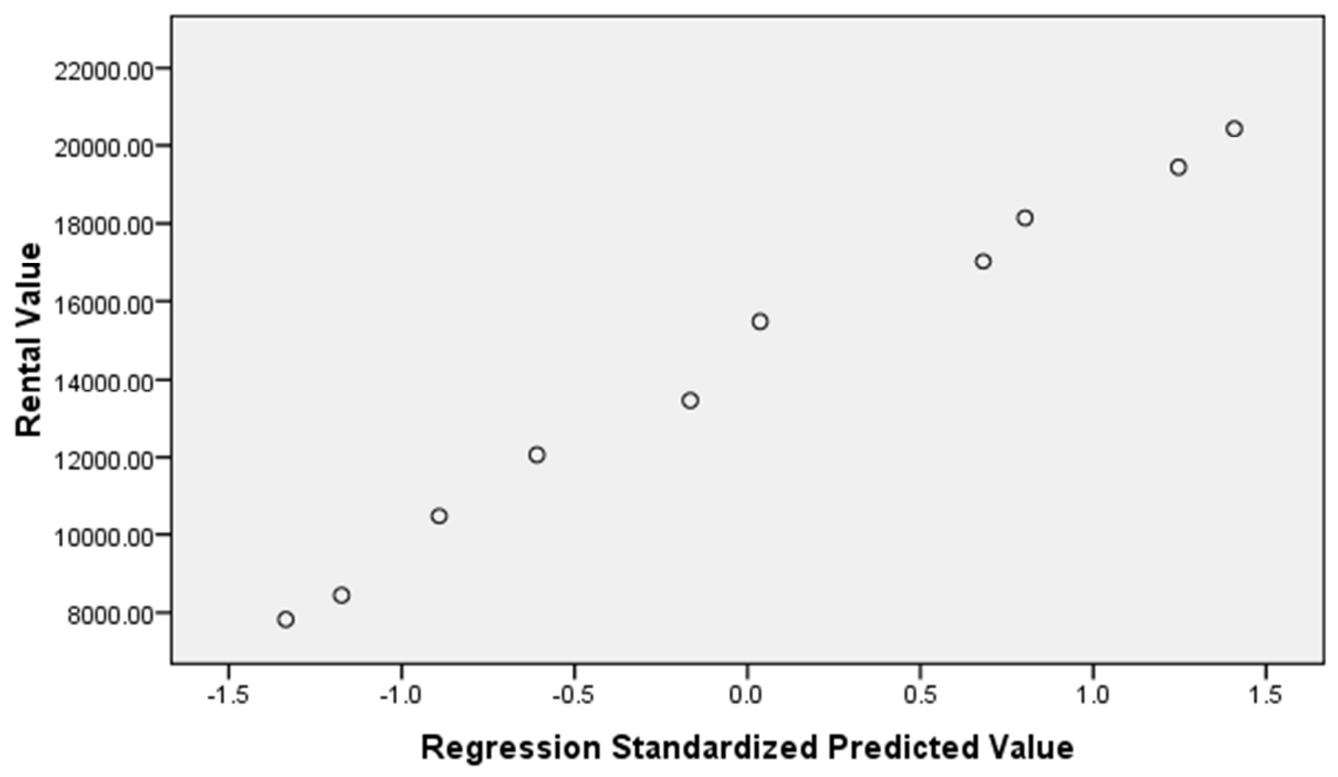

Figure 2. Scatter Plot of Residual Value and Standardized Predicted Value.

The r-squared of the three housing estates compared to the control estate are 0.9766, 0.9320 and 0.8071 for Ehimiri(x), Agbama(a) and Isieke(z) estates respectively. This simply means that 97.66 percent of the control estate is seen in Ehimmiri estate. In order words Ehimmiri estate could explain and represent the control estate up to 97.66 percent.

From the analysis of the regression model to assertion the how fit each and every one of the Housing estates represent the control estate. The worst dilapidation was seen in Isieke when compared to the control estate which shows more lags than other estate. Basically this denotes that rental values of properties in these estates are comparatively different owing to the state of infrastructures which simultaneously should have enhanced real property values. The analysis revealed, as well as confirmed that property rental value in each of the property types appreciate more in Ehimiri housing Estate as compared to the property rental value for the same property type in Agbama housing estate and other. This occurs despite that both housing estates sharing similarities both in the housing estate units design and in the quality of their finishing's. The justifications and supports to these findings should also be qualified by the findings of the infrastructures situations and/or conditions in both housing estates earlier revealed above, as well as to the level of correlation of these essential infrastructures. These, the overall findings objectively confirm that infrastructural provisions were of more available and adequate in Ehimiri Housing Estate as compared to inadequate infrastructural provisions established in Agbama Housing Estate. Hence, this contributes to the sustainable and appreciating rental value of the property types in Ehimiri housing estate than as experienced in Agbama housing estate as compared with the control estate (Zoo Estate in Enugu State). Looking at the correlation coefficients of each housing estate with respect to the control estate, the correlation coefficients above shows that the relationship between the control estate and Ehimiri, Agbama and Isieke signified the most correlated estate to be Ehimmiri followed by Agbama and Isieke.

\section{Conclusion}

Infrastructure is an important element of a good living environment hence; the study examined the effects of delay poor/lack of maintenance will pose on Nigerian housing estates. This empirical survey has established clearly the fact that infrastructure provision and maintenance was critical to the sustainable and appreciating rental as well as capital value of property types in housing estate and even the economic activities functioning in any city at large. The level of relationship between infrastructure decay and rental value across the years was analysed and it demonstrates a positive relationship between infrastructure and rental values across the years. If rental value depends largely on the availability of infrastructure such as water, electricity, good road and many, there is no gainsaying that landlords and property owners will not keep their property habitable for tenants and occupiers of property. The exploration of this study has confirmed that significant provision of this 
infrastructure and its adequate maintenance in housing estates supports sustainable property values and rental value appreciation rationale in housing estate.

In contrary, it should feature dwindling or static property types' rental value in housing estate. The reflection of the study should ensure that adequate provision and maintenance of these indispensable infrastructures are met in any housing estate development by government, individual, organizations and other relevant stakeholders benefiting in housing estate units supply. Further, it should boost the satisfactions and living conditions of the residents/tenants, as well as promoting an improved and sustainable property value of housing estate units. The implication of the findings of the research was that the provision and maintenance of infrastructure, plays a major role in enhancing real property values. The research was limited to the case study area in evaluation of infrastructure decay on property values. Assessing information from EEDC Umuahia and Physical Planning and infrastructure Maintenance fund was difficult. The landlords/tenants were not readily disposed to attend to the researcher on questions pertaining to their feelings on the state of infrastructure in areas where they live.

\section{References}

[1] Ekenta, C. (2010). Infrastructures Provision on Real Property Value: A Comparative Study of Agbama and Ehimiri Housing Estate, Umuahia, Nigeria. International Journal of Environment, Ecology, Family and Urban Studies. 4: 9-20

[2] Hanson, G. and Lloyd, R. (2004). Evaluation of the Social Housing Programme. Yukon: Housing Corporation, Yukon

[3] Canning, D. andBennathan, E. (2000). The Social Rate of Return on Infrastructure Investments: World Bank Working Paper No. 23-90.

[4] Biehl, D. (1986). The Contribution of Infrastructure to Regional Development. Official Publications of the European Communities. Luxembourg.

[5] Ekwueme, J. P (2000). "Government Involvement in Housing" In Effective Housing in 21 stCentury Nigeria, Federal University of Technology Akure, Nigeria, 9-14

[6] Aigbokhan, B. E (1999). Evaluating investment in basic infrastructure in Nigeria, in proceedings of the 8th annual conference on the Zoirah research organized by the research Department, CBN at I-Lamdala Hotel Kaduna, 11th-15th June 199Pp 208.

[7] Babaride, J. A. (1998). Analysis of Industrial location in relation to housing and infrastructure services in metropolitan Lagos:The Lagos Journal of environmental Studies. 1: 97-108.

[8] Ajanlekoko, J. S. (2001). Sustainable Housing Development in Nigeria - The Financial and Infrastructural Implication:Journal of sustainable development. 4:5-6 (2011).

[9] Okusikpe M. O (1999) Environmental Quality and Urban Planning:A case of metropolitan Lagos Nigeria. The Lagos journal of Environmental Studies. 2: 53-63.

[10] Akinmoladun, O. I and Oluwoye, J. (2007). An Assessment of Why the Problems of Housing Shortages Persist in Developing Countries: A case of Study of Lagos Metropolis, Nigeria. Pakistan Journal of Social Science 4(4), 589-598.

[11] Buhr, W. (2003) what is Infrastructure: Department of Economics, School of Economic Disciplines, University of Siegen. Siegen Discussion Paper No. 107-03.

[12] Albala-Bertrand, J. M. and Mamatzakis, E. C. (2004). The Impact of Public Infrastructure on the Productivity of the Chilean Economy: Review of Development Economics 8, 266-278.

[13] Darlow, C. (1984) Valuation and development appraisal. London: Estate Gazette.

[14] Canning, D. and Pedroni, P. (1999). Infrastructure and Long RunEconomic Growth. New York: Mimeo publication.

[15] Cartier-Bresson, J. (1997). Corruption Networks, TransactionSecurity and Illegal Social Exchange. Political Studies 45: 463-476.

[16] Biehl, D. (1991). The Role of Infrastructure in Regional Development, London: Pion publication

[17] Brett Freshman, R. A. (2007). Infrastructure commons in economic perspective:White paper for the Brennan centre of justice. 12:6-4.

[18] Ebie, A. I (2012). Impacts of Inadequate Impact of the Private Provision of Infrastructural Facilities on Housing Cost. B. Tech Project. Federal University of Technology, Akure, Department of Estate Management.

[19] Olatubara, C. O. andFatoye, E. O. (2007). Evaluation of the Satisfaction of Occupants of the Abesan Public Low-Cost Housing Estate in Lagos State, Nigeria:The Nigerian journal of Economic and Social Studies 49:1-3.

[20] Yusif, A. (1998). An Appraisal of Corporate Property Maintenance Practices in Lagos and Oyo State: Journal of Environmental Design and Management. 1:121-132.

[21] Facakin, A. (2004). An African Perspective: In UNHABITAT Debate.10: 4-12.

[22] Federal Republic of Nigeria (1997) Official gazette on 1991 population census.

[23] Federal Republic of Nigeria (1991) National Housing Policy. Lagos: Federal Government Press

[24] Fugita, M. (1990) urban economic theory. London: Cambridge Press.

[25] Fulmer, A. (2009)."Evaluating the Effectivenes of Maintenance Strategies: "Journal of Qualityin Maintenance 12(1):7-20.

[26] Harvey, J.(1993). Urbanlandeconomics. London: Macmillan Education Limited.

[27] Hansen, A. (1965). The Environmental Discourse and Sustainable Development, Linkages and Limitations: Ethicsandthe Environment. 5:3-21.

[28] Casmir On yeneke, et.al. (2018). Weibull Transformation Approach to Formulation of Reliability Model for Analysis of Filth Formation Using Zenith Grinding Machine. American Journal of Aerospace Engineering. Vol. 5, No.1, 2018, pp. 3038. doi:10.11648/j.ajae.20180501.15. 

Decay on Rental Values in Nigeria (Case Study of Ehimiri, Agbama and Isieke Housing Estates)

[29] Onyeneke C. C. (2015). Multivariate Approach to Partial Correlation Analysis: Science Journal of Applied Mathematics and Statistics. Vol. 3, No. 3, 2015, pp. 165-170. doi:10.11648/j.sjams.20150303.20
[30] Onyeneke C. C., Effanga O. E. (2016). Application of Reduced Second Order Response Surface Model of Convex Optimizationin Paper Producing Industries: International Journal of Theoretical and Applied Mathematics. Vol. 2, No. 1, 2016, pp. 13-23. doi:10.11648/j.ijtam.20160201.13. 